\title{
Decimeter scale heterogeneity in the plankton during a pycnocline bloom of Gyrodinium aureolum
}

\author{
Peter Koefoed Bjørnsen ${ }^{1}$, Torkel Gissel Nielsen ${ }^{2}$
}

\begin{abstract}
${ }^{2}$ Marine Biological Laboratory, University of Copenhagen, Strandpromenaden 5, DK-3000 Helsingør, Denmark
${ }^{2}$ Danish Institute for Fisheries and Marine Research, Charlottenlund Castle, DK-2920 Charlottenlund, Denmark
\end{abstract}

\begin{abstract}
Vertical heterogeneity of pelagic organisms in a subsurface bloom of Gyrodinium aureolum (Hulburt) was studied on the decimeter scale by a high resolution sampler in the Kattegat, Denmark, during August 1990. Maximum concentrations of $3.25 \times 10^{6} \mathrm{G}$. aureolum $\mathrm{l}^{-1}$ and $72 \mathrm{\mu g}$ chlorophyll a $\mathrm{I}^{-1}$ were recorded in the pycnocline at a depth of $14 \mathrm{~m}$ with $5 \%$ of surface irradiance. Dinoflagellates were confined to a $1 \mathrm{~m}$ thick layer which contained more chlorophyll than the rest of the water column. In situ primary production rates suggested a phytoplankton turnover time of $1 \mathrm{~d}$. Bacterioplankton production and turnover rate and microzooplankton abundance were significantly reduced in the dinoflagellate layer
\end{abstract}

\section{INTRODUCTION}

The Kattegat and the Skagerrak, situated between Denmark, Sweden and Norway, form the mouth of the Baltic Sea, which may be regarded as the world's largest estuary. During summer these waters are stratified into a surface layer of outflowing Baltic water with a salinity of 10 to $20 \mathrm{ppt}$ and a bottom layer of counterflowing North Sea water with a salinity of 30 to 33 ppt. The stratification is further stabilized by solar heating of the surface layer.

The establishment of stratification and the increasing insolation in spring trigger a diatom spring bloom which rapidly depletes the surface water of nutrients, and the diatoms eventually precipitate to the bottom Nutrient concentrations in the surface water remain low throughout summer and primary production becomes limited by nutrients supplied by remineralisation in the surface layer and via transport through the pycnocline. Nutrient inputs from riverine and diffusive runoff may support new production in the surface water. However, on a regional scale most of these inputs are assimilated and precipitated in the Baltic Proper (Larsson et al. 1985, Rydberg et al. 1990). Phytoplankton biomasses of less than a few $\mu \mathrm{g}$ of chlorophyll a $\mathrm{l}^{-1}$ are usually recorded during the summer in surface waters of the Kattegat and the Skagerrak (Lindahl \& Hernroth 1983, Richardson \& Christoffersen unpubl.).
Recently, attention has been drawn towards the occurrence of high densities of phytoplankton confined to a narrow subsurface stratum of the water column around the pycnocline. During May-June 1988, the toxic flagellate Chrysochromulina polylepis was found in a 1 to $2 \mathrm{~m}$ wide layer in the pycnocline throughout the Kattegat (Barth \& Nielsen 1989, Nielsen et al. 1990). Cell densities reached $70 \times 10^{6}$ cells $1^{-1}$. A recurrent phenomenon in the Kattegat during early autumn is the occurrence of dinoflagellate subsurface blooms, including Ceratium spp. and the toxic Gyrodinium aureolum (Lindahl \& Hernroth 1983, Nielsen 1991). These active phytoplankton layers seem to appear where the oppositely directed gradients of light penetrating from above and nutrients permeating the pycnocline from below meet to sustain primary production. The phytoplankton assemblage in the pycnocline thus acts as a 'filter' to the upwards flux of nutrients, and thereby impedes the build up of phytoplankton biomass in the surface layer that would reduce light penetration to the pycnocline.

Narrow subsurface layers of phytoplankton are easily recognized by in situ fluorometry, but they can be quite inaccessible to accurate sampling by conventional water samplers. Furthermore, narrow layers of phytoplankton are likely to be maintained by steep physico-chemical gradients, that may give rise to a biological stratification of the phytoplankton, and - 
possibly in response to the phytoplankton - of the heterotrophic organisms as well. In order to improve quantitative sampling of subsurface phytoplankton layers and to examine a possible stratification within such layers, we constructed a high resolution gradient multisampler. We here report on the use of this sampler during a subsurface dinoflagellate bloom.

\section{MATERIALS AND METHODS}

The gradient multi-sampler takes 20 duplicate water samples simultaneously at $15 \mathrm{~cm}$ intervals (Fig. 1). Twenty plastic syringes of $150 \mathrm{ml}$ (Monoject, Sherwood Medical, N. Ireland) are mounted on each side of a $300 \times 75 \mathrm{~cm}$ aluminium frame. The pistons in each pair of syringes are hooked onto the frame by a modified plug, which is spring-loaded by rubber tubing. The loaded sampler is fixed on a wire and lowered to the desired depth. The assymmetrical position of the wire ensures that the syringe openings will face any existing current. Dropping a messenger weight releases all hooks simultaneously via a slide rod inside the frame, and the pistons are pulled by the rubber tubings until they reach a stop bar. Video recordings have shown that the syringes fill within $0.8 \mathrm{~s}$.

The sampler was deployed on 15 August 1990 at a permanent station in the Southern Kattegat $\left(56^{\circ} 15^{\prime} 42^{\prime \prime} \mathrm{N}, 12^{\circ} 00^{\prime} 12^{\prime \prime} \mathrm{E}\right)$. Continuous vertical profiles of fluorescence were recorded on 5 occasions at the same station by a $Q$ Instruments in situ fiuorometer connected to an X-Y plotter. Temperature and salinity were recorded at $2 \mathrm{~m}$ depth intervals using a SalinityTemperature Bridge (Type MC5, Electronic Swithgear Ltd, London). Subsamples were taken from the gradient sampler for microscopy and measurements of chlorophyll $a$, primary production and thymidine incorporation.

Chlorophyll a was determined from $100 \mathrm{ml}$ samples (1 per depth) filtered onto GF/C filters, extracted in ethanol and measured fluorometrically (Jespersen \& Christoffersen 1987). The 5 densest samples were also measured spectrophotometrically according to Lorenzen (1967). Primary production was measured in $8 \mathrm{ml}$ subsamples ( 2 per depth) contained in $10 \mathrm{ml}$ plastic syringes. Two $u \mathrm{Ci}$ of $\mathrm{NaH}^{14} \mathrm{CO}_{3}$ were injected into each sample. The syringes were fixed onto a string and incubated in situ at the original depth for $2 \mathrm{~h}$ around noon. Incubations were stopped by $200 \mu \mathrm{I}$ of $1 \mathrm{~N} \mathrm{HCl}$. Samples were bubbled for $30 \mathrm{~min}$ and radioassayed. Parallel dark incubations were subtracted as blanks. Dissolved inorganic carbon (DIC) was estimated from an empirical relationship to salinity (authors unpubl. results): DIC $(\mathrm{mM})=1.3+0.02$ Salinity $(\mathrm{ppt})$. Thymidine incorporation rate was measured in duplicate

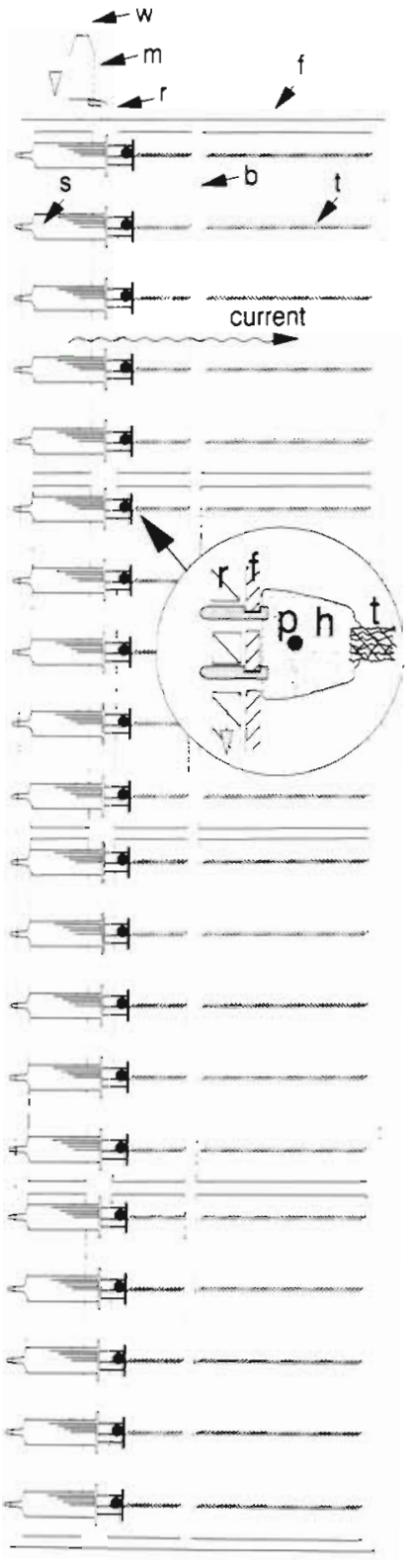

Fig. 1. Side view of the gradient sampler. f: aluminium frame; $s: 150 \mathrm{ml}$ syringe $e_{\text {i }}$ : rubber tubing; $b$ : stop bar; $r$ : release slide rod; $\mathrm{m}$ : messenger weight; $\mathrm{w}$ : wire. Inserted detail of release mechanism: h: hook plug; $\mathrm{p}$ : piston pull

$10 \mathrm{ml}$ samples at each depth according to Fuhrman \& Azam (1980), using $5 \mathrm{nM}\left[{ }^{3} \mathrm{H}\right]$-Thymidine, formalin fixation, cold ICA extraction and pre-killed blanks. Autotrophic flagellates and cyanobacteria were enumerated by epifluorescence microscopy of $5 \mathrm{ml}$ samples stained by proflavine hemisulphate, fixed by $0.5 \%$ glutar aldehyde and filtered onto $0.2 \mu \mathrm{m}$ filters (Haas 1982), Bacterioplankton were counted according to Hobbie et al. (1977), and microzooplankton were enumerated by inverted microscopy of settled $50 \mathrm{ml}$ samples. 


\section{RESULTS}

A pronounced fluorescence peak close to the pycnocline was observed at the permanent station during the entire month of August 1990 (Fig. 2). On 15 August the pycnocline was situated at 14 to $15 \mathrm{~m}$ depth and a strong peak in chlorophyll a was found at 14 to $14.5 \mathrm{~m}$ depth (Fig. 3), where irradiance was about $5 \%$ of surface irradiance (data not shown). One pair of sampling syringes contained $72 \mu \mathrm{g}$ chlorophyll $a 1^{-1}$ as determined spectrophotometrically and the concentration decreased by a factor of 3 to 5 within $30 \mathrm{~cm}$. Chlorophyll a concentration in the mixed surface and bottom layers was 3.5 and $0.7 \mu \mathrm{g} \mathrm{l}^{-1}$, respectively. Hence, more than half of the chlorophyll $a$ in the water column was confined within the pycnocline.

Microscopy revealed that phytoplankton in the pycnocline was completely dominated by the dinoflagellate Gyrodinium aureolum (Hulburt). Maximum

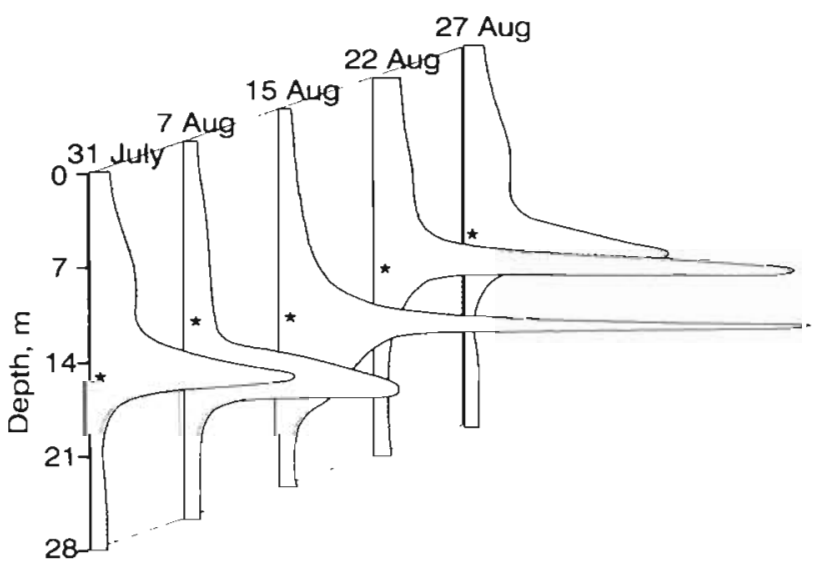

Fig. 2. Depth profiles of in situ fluorescence (arbitrary units) on 5 dates in 1990 in Southern Kattegat. Asterisks indicate position of the pycnocline

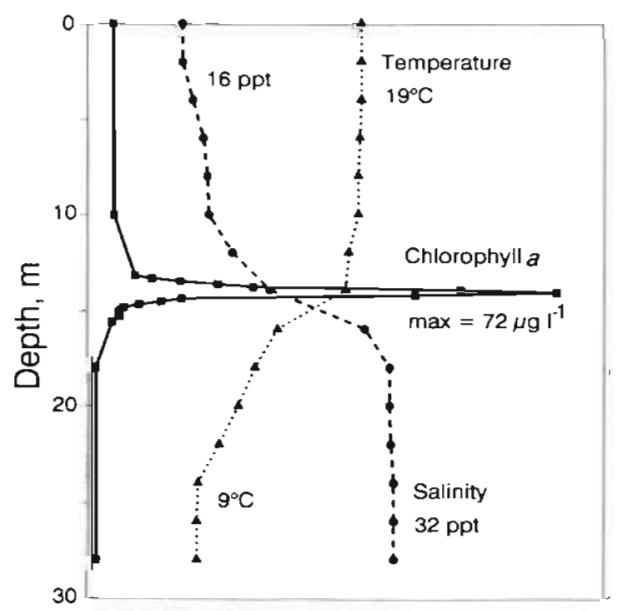

Fig. 3. Depth profiles of salinity, temperature and chlorophyll a on 15 August 1990 in Southern Kattegat cell density was $3.25 \times 10^{6}$ cells $1^{-1}$ compared to

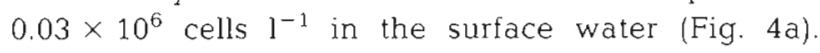
Cyanobacteria were also abundant in the pycnocline

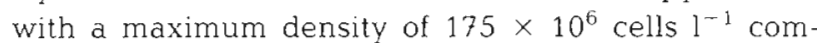
pared to $90 \times 10^{6}$ cells $1^{-1}$ in the surface water. However, their biomass contributed only by a few percent of the total phytoplankton in the pycnocline

Primary production showed a peak of $192 \mu \mathrm{g} \mathrm{C} \mathrm{l}^{-1}$ $\mathrm{h}^{-1}$ with a slight upwards displacement from the chlorophyll a peak (Fig. 4b). Specific primary productivity ('assimilation number' calculated as the ratio between in situ primary production and chlorophyll a concentration) also showed a distinct maximum of about $4 \mu \mathrm{g} \mathrm{C} \mathrm{h}{ }^{-1}$ per $\mu \mathrm{g}$ chlorophyll $a$ at the upper shoulder of the production peak (Fig. 4b). Assuming a phytoplankton carbon to chlorophyll a ratio of 30 (Parsons et al. 1984), the turnover rate of the phytoplankton assemblage in the pycnocline was $0.09 \mathrm{~h}^{-1}$ at the given light conditions. Bacterioplankton cell number almost doubled in the Gyrodinium aureolum layer, whereas bacterial production measured as thymidine incorporation rate showed a decrease to about half of the surrounding values (Fig. $4 \mathrm{c}$ ). Microzooplankton showed a distinct negative response to the $G$. aureolum layer (Fig. 4d). Naked oligotrichous ciliates and tintinnids were absent in the center of the layer, and density of the heterotrophic dinoflagellate Protoperidinium sp. was significantly reduced. Correlation analysis between phytoplankton biomass or production versus bacterial number and activity and microzooplankton abundance (Table 1) confirmed the trends in Fig. 4.

\section{DISCUSSION}

The vertical structure of the plankton observed on 15 August 1990 (Figs. 3 \& 4) seemed to be a pattern of considerable temporal and geographical extension. At the permanent station, the fluorescence peak in the pycnocline persisted throughout August (Fig. 2), although significant quantitative variations (up to a factor of 2 in maximum fluorescence) were observed between successive casts (data not shown). A monitoring cruise carried out by the Danish Ministry of Environment in late July recorded a distinct subsurface bloom of Gyrodinium aureolum at all 4 stations visited in the Kattegat (Kurt Buck et al, unpubl., Gunni Ærtebjerg pers. comm.). We suppose that $G$. aureolum formed a more or less coherent 'magic carpet' in the pycnocline of the Kattegat. This phenomenon is fundamentally different from the small-scale 3-dimensional patchiness described by e.g. Derenbach et al. (1979) and Mitchell \& Fuhrman (1989).

Several mechanisms may contribute to form and maintain a layer of high phytoplankton biomass in the 


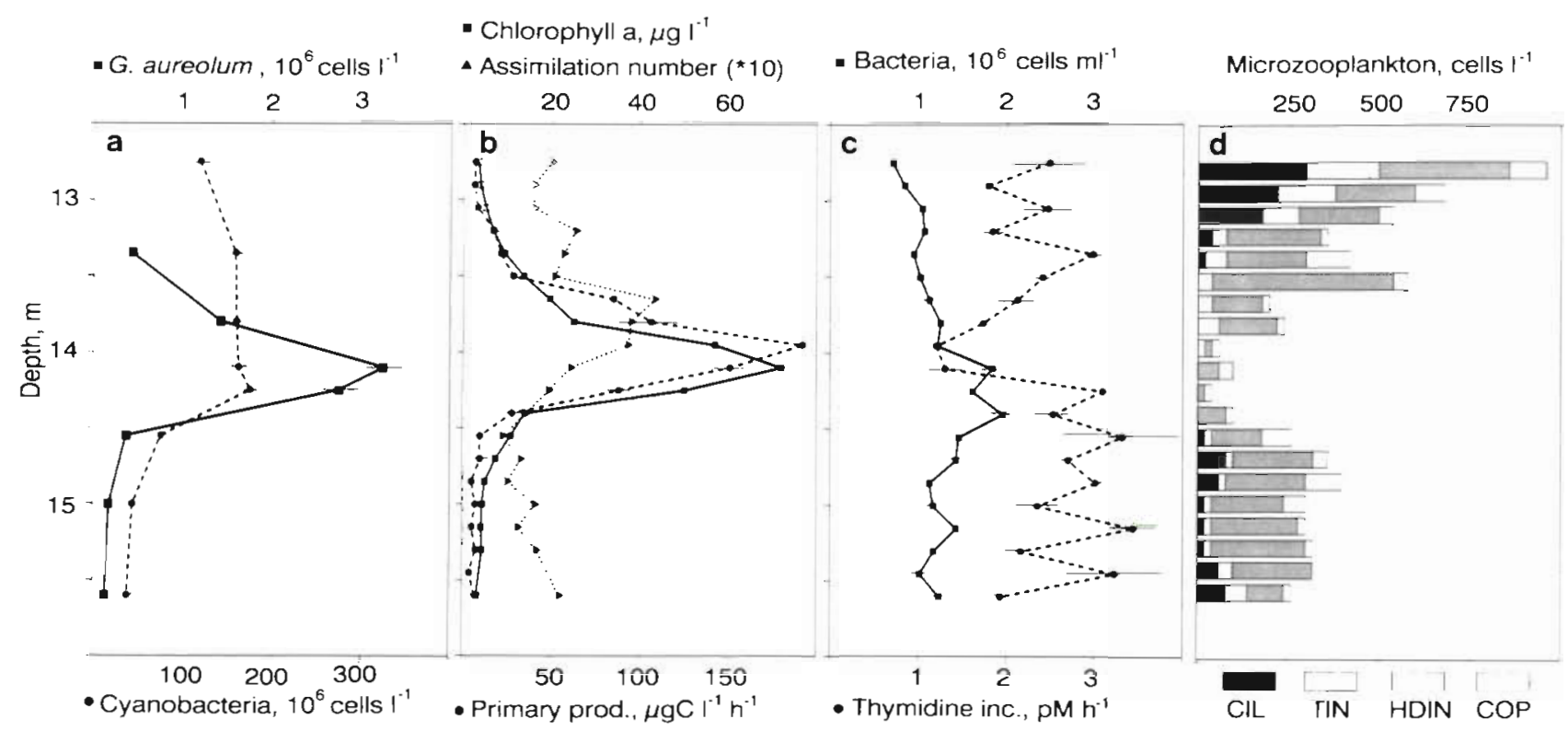

Fig. 4. Biological stratification within the pycnocline. (a) Densities of Gyrodinium aureolum and cyanobacteria. (b) Chlorophyll a, primary production and specific primary productivity ('assimilation number' defined as the ratio between primary production and chlorophyll $\mathrm{a}, \mu \mathrm{g} \mathrm{C} \mathrm{h}{ }^{-1}$ per $\mu \mathrm{g} \mathrm{chl} \mathrm{a).} \mathrm{(c)} \mathrm{Bacterioplankton} \mathrm{cell} \mathrm{density} \mathrm{and} \mathrm{thymidine} \mathrm{incorporation} \mathrm{rate.} \mathrm{(d)} \mathrm{Microzooplank-}$ ton density shown as stacked bars of: 'CIL = oligotrichous ciliates (size ca $40 \mu \mathrm{m}$ ), 'TIN' = tintinnids (ca $40 \mu \mathrm{m}$ ), 'HDIN' = Protoperidinium sp. (ca $100 \mu \mathrm{m}$ ) and 'COP' = juvenile copepods. Horizontal bars represent standard errors (a) or ranges of duplicates $(b, c)$. Open symbols indicate interpolated values

Table 1. Correlation coefficients ( $\mathrm{r}$ ) between chlorophyll a (CHL) or primary production (PP) versus bacterial number (BACT), thymidine incorporation rate (TTI), bacterial turnover rate (BTO), and abundances of oligotrichous ciliates (CIL), tintinnids (TIN), Protoperidinium sp. (HDIN) and juvenile copepods (COP). All values were transformed to logarithms (microzooplankton abundance as $\log (x+1)$ ) to obtain normal distributed data. Asterisks indicate significance (" $p<5 \%$, $\cdots p<1 \%, \cdots p<0.1 \% 1$

\begin{tabular}{|lll|}
\hline & \multicolumn{1}{c}{ CHL } & \multicolumn{1}{c|}{ PP } \\
\hline BACT & $+0.545^{\circ}$ & +0.407 \\
TTI & $-0.456^{\circ}$ & $-0.586^{\circ} \cdots$ \\
BTO & $-0.689^{\cdots}$ & $-0.699^{\cdots} \cdots$ \\
CIL & $-0.856^{\cdots}$ & $-0.859^{\circ}$ \\
TIN & $-0.616^{\cdots}$ & $-0.458^{\circ}$ \\
HDIN & $-0.729^{\cdots}$ & $-0.661^{\cdots}$ \\
COP & -0.030 & -0.033 \\
\hline
\end{tabular}

pycnocline: (1) high irradiance and reduced windinduced mixing; (2) passive accumulation of cells by sedimentation combined with a deceleration of sinking rate in the pycnocline (Bienfang et al. 1983); (3) phototaxis combined with active responses to gradients of salinity and nutrients (Rasmussen \& Richardson 1989); (4) enhanced growth due to the combined effects of light and nutrients, cf. above; and (5) reduced mortality from zooplankton grazing due to avoidance of the phytoplankton layer (Fiedler 1982).
It seems unlikely that sedimentation would be a major factor in the establishment of the observed pronounced and narrow dinoflagellate peak. Phototaxis has been demonstrated for Gyrodinium arueolum and other dinoflagellates (e.g. Ekelund \& Häder 1988), and laboratory studies have shown that the phototactic response of Gonyaulax tamarensis is suppressed by a salinity gradient of $>7 \%$ and by the absence of nutrients (Rasmussen \& Richardson 1989). The steepest salinity gradient in the present study was ca 5 ppt over a few decimeters (Fig. 3). The 2-fold increase in assimilation number (Fig. 4 b) suggests that phytoplankton growth was actually enhanced in the pycnocline. The phytoplankton layer would absorb about half of the irradiation (assuming a specific attenuation coefficient of $0.018 \mathrm{~m}^{-1}$ per $\mathrm{mg}$ chlorophyll $\mathrm{m}^{-3}$; Taylor et al. 1986), so the lower shoulder of the assimilation number peak can be explained by light limitation, while the upper shoulder may perhaps be due to nutrient limitation. The maximum of about 4 ug $\mathrm{C} \mathrm{h}^{-1}$ per $\mathrm{ug}$ chlorophyll a suggests that the dinoflagellates were well adapted to low light levels. The increased abundance of cyanobacteria in the pycnocline (Fig. 4a), though much less pronounced than for dinoflagellates, also indicated enhanced growth and/or reduced mortality

The apparent microzooplankton avoidance of the phytoplankton layer (Fig $4 \mathrm{~d}$ ) and the reduced thymidine incorporation despite higher bacterial cell numbers in the layer (Fig. 4c) indicate that high densities of 
Gyrodinium aureolum may have toxic or inhibitory effects on these heterotrophic organisms. We have previously reported on similar effects on the planktonic community by a monospecific subsurface bloom of Chrysochromulina polylepis (Nielsen et al. 1990). Blooms of $G$. aureolum have often been associated with fish and invertebrate mortality (Tangen 1977), and laboratory studies have demonstrated toxic effects on a variety of marine organisms, including fish (Roberts et al. 1983), shellfish (Erard-le Denn et al. 1990), copepods (Gill \& Harris 1987) and phytoplankton (Gentien \& Arzul 1990). Inhibition of potential predators could be an important factor in the maintenance of a high phytoplankton biomass in the pycnocline. Phytoplankton may be transported from this 'refuge' to frontal areas and appear as a surface bloom (Richardson \& Kullenberg 1987). Narrow subsurface phytoplankton layers may be missed or inadequately sampled by routine monitoring programmes, and the biological stratification within the layers is disrupted by conventional bottle sampling.

Acknowledgements. We thank A. C. Nielsen, L. Knudsen and B. Thrue for technical assistance; P. J. Hansen, J. Larsen and $M$. Olesen for data and information; and T. Fenchel and K. Richardson for criticism on the manuscript. We acknowledge financial support from the Danish Natural Science Research Council (J. nr. 11-7234) and from the National Agency for Environmental Protection in Denmark (project HF-90.2.03B).

\section{LITERATURE CITED}

Barth, H., Nielsen. A. (1989). The occurrence of Chrysochromulina polylepis in the Skagerrak and Kattegat in May/June 1988: an analysis of extent, effects and causes. Commission of the European Communities, Luxembourg Water pollution research report 10

Bienfang, P., Szyper, J., Laws, E. (1983). Sinking rate and pigment response to light-limitation of a marine diatom: implications to dynamics of chlorophyll maximum layers Oceanol. Acta 6: 55-62

Derenbach, J. B., Astheimer, H., Hansen, H. P., Leach, H. (1979). Vertical microscale distribution of phytoplankton in relation to the thermocline. Mar Ecol. Prog. Ser. 1 $187-193$

Ekelund, N., Häder, D.-P. (1988). Photomovement and photobleaching in two Gyrodinium species. Plant Cell Physiol. 29: $1109-1114$

Erard-le-Denn, E., Morlaix, M., Dao, J. C. (1990). Eftects of Gyrodinium of. aureolum on Pecten maximus (post larvae, juveniles and adults). In: Graneli, E., Sundstrom, B., Edler, L., Anderson, D. M. (eds.) Toxic marine phytoplankton. Elsevier, New York, p. 132-136

Fiedler, P. C. (1982). Zooplankton avoidance and reduced grazing responses to Gymnodinium splendens (Dinophyceae). Limnol. Oceanogr. 27: 961-965

This article was submitted to the editor
Fuhrman, J. A., Azam, F. (1980). Bacterioplankton secondary production estimates for coastal waters off British Columbia, Antarctica and California. Appl. environ. Microbiol. 39: 1085-1095

Gentien, P., Arzul, G. (1990). Exotoxin production by Gyrodinium cf. aureolum (Dinophyceae). J. mar biol. Ass. U.K. 70:571-581

Gill, C. W., Harris, P. P. (1987). Behavioural responses of the copepods Calanus helgolandicus and Temora longicomis to dinoflagellate diets. J. mar biol. Ass. U.K. 67: 785-801

Haas, L. W (1982). Improved epifluorescence microscopy for observing planktonic micro-organisms. Ann. Inst. Océanogr., Paris 58 (Suppl.): 261-266

Hobbie, J. E., Daley, R. J., Jaspers, S. (1977). Use of Nuclepore filters for counting bacteria by epifluorescence. Appl. environ. Microbiol. 33: 1225-1228

Jespersen, A.-M., Christoffersen, K. (1987). Measurement of chloropyhll a from phytoplankton using ethanol as extraction solvent. Arch. Hydrobiol. 109: 445-454

Larsson, U., Elmgren, R., Wulff, F. (1985). Eutrophication and the Baltic Sea: causes and consequences. Ambio 14: 9-14

Lindahl, O., Hernroth, L. (1983). Phyto-zooplankton community in the coastal waters of Western Sweden - an ecosystem off balance. Mar. Ecol. Prog. Ser 10: 119-126

Lorenzen, C. J. (1967). Determination of chlorophyll and phaeopigments: spectrophotometric equations. Limnol. Oceanogr 12: 343-346

Mitchell, J. G., Fuhrman, J. A. (1989). Centimeter scale vertical heterogeneity in bacteria and chlorophyll a. Mar. Ecol. Prog. Ser 54. 141-148

Nielsen, T G. (1991). Contribution of zooplankton grazing to the decline of a Ceratium bloom. Limnol. Oceanogr (in press)

Nielsen, T G., Kiorboe, T., Bjornsen. P. K., (1990). Effects of a Chrysochromulina polylepis subsurface bloom on the planktonic community. Mar Ecol. Prog. Ser. 62: 21-35

Parsons, T R., Takahashi, M., Hargrave. B. (1984). Biological oceanographic processes, 3rd edn. Pergamon Press, New York

Rasmussen, J., Richardson, K. (1989). Response of Gonyaulax tamarensis to the presence of a pycnocline in an artificial water column. J. Plankton Res. 11: 747-762

Richardson, K., Kullenberg, G. (1987). Physical and biological interactions leading to phytoplankton blooms: a review of Gyrodinium aureolum blooms in Scandinavian waters Rapp. P.-v. Réun. Cons. int. Explor. Mer 187: 19-26

Roberts, R. J., Bullock, A. M., Turner, M., Jones, K., Tett, P. (1983). Mortalities of Salmo gairdneri exposed to Gyrodinium aureolum. J. mar. biol. Ass. U.K. 63: 741-743

Rydberg, L., Edler, L., Floderus, S., Granéli, W. (1990). Interactions between supply of nutrients, primary production, sedimentation and oxygen consumption in the SE Kattegat. Ambio 19: 134-141

Tangen, K. (1977). Blooms of Gyrodinium aureolum (Dinophyceae) in North European waters, accompanied by mortality in marine organisms. Sarsia 63: 123-134

Taylor, A. H., Harris, J. R. W., Aiken, J. (1986). The interaction of physical and biological processes in a model of the vertical distribution of phytoplankton under stratification. In: Nihoul, J. C. J. (ed.) Marine interfaces ecohydrodynamics. Elsevier Oceanography Series 42, Amsterdam, p. $313-331$

Manuscript first received: February 14, 1991

Revised version accepted: April 22, 1991 